\title{
Knowledge, attitude, and behaviors of pregnant women about COVID-19: a single-center cross-sectional study
}

\author{
Gökçe Turan $^{1}$ (D), Gülnur Kul ${ }^{2}$ (D) , Ezgi Turgut ${ }^{1}$ (D) \\ ${ }^{1}$ Department of Obstetrics \& Gynecology, School of Medicine, Gazi University, Ankara, Turkey \\ ${ }_{2}^{2}$ Infectious Diseases Clinic, Kırıkhan State Hospital, Hatay, Turkey
}

\begin{abstract}
Objective: Our aim is to assess the knowledge, attitude, and behaviors of pregnant women about COVID-19.

Methods: This cross-sectional survey study was performed on pregnant women in their second and third trimesters between November-December 2020. The participants completed a questionnaire consisting of 5 parts. Demographic data of pregnant women, their knowledge, attitude, and risk perceptions toward COVID-19, their practices and worries about COVID-19, and what they knew about pregnancy were calculated as percentile and mean values.

Results: A total of 1011 participants were included in the statistical analysis. The mean age and BMI of the participants were $27.09 \pm 5.55$ and $27.48 \pm 4.71 \mathrm{~kg} / \mathrm{m}^{2}$, respectively. Mean gestational age and parity were $26.20 \pm 9.30$ and $1.47 \pm 1.19$, respectively. Measures taken by authorities for COVID-19 were thought to be "extremely adequate" by $21.4 \%$ of the participants and "highly adequate" by $30 \%$. Of the participants, $47.5 \%$ trusted healthcare professionals extremely in fighting against the COVID-19 pandemic. Affection and respect for healthcare professionals during the pandemic increased in $89.1 \%$ of the participants. Of the participants, $88.5 \%$ stated that they would follow the strict quarantine requirements when necessary and $48.3 \%$ felt more vulnerable/weak as they were pregnant during the pandemic. Of the participants, $50.6 \%$ were intending to decrease their antenatal visits during the COVID-19 pandemic.

Conclusion: The measures taken can be applied with high awareness of COVID-19. Sufficient training, in that case, can be done through communication routes such as information and public service announcements.
\end{abstract}

Keywords: COVID-19, awareness, attitude, knowledge, coronavirus.

\section{Introduction}

A novel coronavirus ( $\mathrm{nCoV}$ ) that has recently been detected is called "SARS-CoV-2", and causes "2019 coronavirus disease (COVID-19)". ${ }^{[1]}$ The clinical course
Özet: Gebelerin COVID-19'a yönelik bilgi, tutum ve davranışları: Tek merkezli kesitsel çalışma

Amaç: Amacımız, gebelerin COVID-19'a yönelik bilgilerini, tutumlarını ve davranışlarını değerlendirmektir.

Yöntem: Bu kesitsel anket çalışması, Kasım-Aralık 2020 tarihleri arasında ikinci ve üçüncü trimesterlerinde olan gebelerle gerçekleştirildi. Katılımcılar 5 bölümden oluşan bir anketi yanıtladı. Gebelerin demografik verileri, COVID-19'a yönelik bilgileri, tutumları ve risk algıları, COVID-19'a ilişkin uygulamaları ve endişeleri ile gebelik hakkındaki bilgileri, persantil ve ortalama değer olarak hesaplandi.

Bulgular: İstatistiksel analize toplam 1011 katllımc dahil edildi. Katılımcıların ortalama yaşı ve VKİ değerleri sırasıyla $27.09 \pm 5.55$ ve $27.48 \pm 4.71 \mathrm{~kg} / \mathrm{m}^{2}$ idi. Ortalama gestasyonel yaş ve parite ise s1rasivla $26.20 \pm 9.30$ ve $1.47 \pm 1.19$ 'du. Yetkililerin aldığ COVID-19 tedbirleri, katılımciların \%21.4'ü tarafindan "son derece yeterli", \%30'u tarafindan ise "yüksek derecede yeterli" bulundu. Katılımc1ların $\% 47.5{ }^{`} \mathrm{i}$, COVID-19 pandemisiyle mücadelede sağlık çalışanlarına son derece güvendiğini belirtti. Pandemi sürecinde sağllk çalışanlarına ilgi ve saygı, katılımciların \%89.1'inde arttı. Katılımcıların \% $88.5^{\prime} \mathrm{i}$ gerektiğinde katı karantina kurallarına uyacağını belirtirken, \%48.3'ü ise pandemi sırasında hamile olduklarından daha savunmasız/zayıf olduklarını hissetti. Katılımcıların \%50.6'sı COVID-19 pandemisi boyunca antenatal ziyaretlerini azaltmayı planliyordu.

Sonuç: Alınan tedbirler, yüksek COVID-19 farkındalığı ile uygulanabilir. Bu durumda, bilgilendirme ve kamu spotları gibi iletişim yöntemleriyle yeterli eğitim sağlanabilir.

Anahtar sözcükler: COVID-19, farkındalık, tutum, bilgi, koronavirüs.

of COVID-19 may range from an asymptomatic course or mild respiratory symptoms to death. ${ }^{[1]}$

COVID-19 is an infectious disease caused by a novel coronavirus family with a clinical course that has not

Correspondence: Gökçe Turan, MD. Department of Obstetrics \& Gynecology, School of Medicine, Gazi University, Beşevler, Ankara, Turkey. e-mail: drgokceturan@gmail.com / Received: August 15, 2021; Accepted: September 23, 2021

How to cite this article: Turan G, Kul G, Turgut E. Knowledge, attitude, and behaviors of pregnant women about COVID-19: a single-center crosssectional study. Perinatal Journal 2021;29(3):186-193. doi:10.2399/prn.21.0293003

ORCID ID: G. Turan 0000-0002-2443-1927; G. Kul 0000-0001-7317-3461; E. Turgut 0000-0002-5509-7888 
been completely defined for the elderly and immunosuppressive populations including, especially pregnant women. ${ }^{[2]}$ Previous experiences with pregnant women during influenza, H1N1, SARS, and MERS pandemics caused significant concerns about the course of COVID19 in obstetrics. These previous infections caused more severe disease courses with increased ICU admission and case-fatality rates in pregnant women compared to the general population. ${ }^{[2,3]}$ Some authors report that the pregnant population and general population have similar mortality and morbidity rates. ${ }^{[4]}$

Awareness, attitudes, and level of knowledge have been studied in several previous outbreaks such as swine flu, ${ }^{[5]}$ MERS, ${ }^{[6]}$ and Dengue fever. ${ }^{[7]}$ It was revealed that higher awareness of these diseases is also effective in controlling the spread of these viruses in addition to positive attitudes and behaviors toward these diseases. Although the information about maternal, fetal, and clinical results of COVID-19 in pregnant women is still inconsistent, these outbreaks negatively affect the mental health of pregnant women as far as we know from previous outbreaks. ${ }^{[8]}$ These mental effects may be important of the clinical ones in those patients with mild-moderate symptoms or asymptomatic. ${ }^{[8]}$

Due to the rapid spread of COVID-19, strict measures have been taken and some restrictions have been set in many countries. Pregnant women have mentally been affected by these measures taken and restrictions put to prevent the spread of COVID-19. It is also emphasized in the guideline published by the Royal College of Obstetricians and Gynecologists that the COVID-19 pandemic increases the risk of perinatal anxiety, depression, and domestic violence, and therefore, it is very important to support pregnant women psychologically. ${ }^{[0]}$

Therefore, this study aimed to assess the knowledge, attitude, and behaviors of pregnant women about COVID-19, measure their level of awareness and knowledge on prevention of the COVID-19, and help all authorized people in charge of controlling the pandemic to obtain evidence-based data.

\section{Methods}

This cross-sectional questionnaire study was performed in a secondary care hospital between the 15th of November 2020 and the 15th of December 2020. Informed consent forms of all participants were obtained. The study was approved by the local institutional administration board (Number: 2020-0922T14_07_53). All procedures of the study were in compliance with the 1964 Helsinki Declaration and its later amendments or comparable ethical standards and the ethical standards of the institutional and/or national research committee. The inclusion criteria were being in the second and third trimesters with a healthy pregnancy and being admitted to the pregnancy outpatient clinic of the hospital. The exclusion criteria were having signs or symptoms of COVID-19, being among those whose labor began or who were suspected of birth, those who had to be hospitalized due to an obstetric reason, and those with an available or pre-existing psychiatric disorder. In addition, the pregnant women who did not want to participate in the study, those younger than 18 , and those in the first trimester of the pregnancy were also excluded from the study. The study was prospectively performed and approved by the Ethics Committee of Hatay Mustafa Kemal University Faculty of Medicine (Ethics Committee Number: 2020/15). After the related literature was reviewed by the researchers, a questionnaire consisting of 5 parts was prepared for the patients. The participants were informed and the aim of the study was explained in detail before interviews.

The questionnaire applied to the participants consisted of 5 parts. The demographical data of the participants were questioned in the first part. The second part questioned the "knowledge on Covid-19" of the pregnant women with a total of 9 questions. The third part questioned the "attitudes and risk perceptions of pregnant women on Covid-19" with 7 questions, and the responses were recorded as "yes", "no", and "I do not know". In the fourth part of the questionnaire, the "practices of the pregnant women on Covid-19" were evaluated with 8 questions, and the responses were recorded as "always", "often"," sometimes", "rarely", and "never". In the 5th and final part of the questionnaire, the "concerns and knowledge of the pregnant women on Covid-19" were evaluated. The responses were evaluated with 8 questions as "yes", "no", and "I do not know". The participants anonymously completed the questionnaires within 2-3 minutes on average.

Data collected through the questionnaires were analyzed with SPSS 20.0 (Statistical Package for the Social Sciences Inc.; Chicago, IL, USA) software program. Statistical assessment was expressed as mean \pm standard deviation (mean $\pm \mathrm{SD}$ ) and count (percentage). 


\section{Results}

Participants who were admitted to the maternity outpatient clinic of a secondary care hospital between the 15th of November 2020 and 15th of December 2020 and who met the inclusion criteria were included in the study. Out of 1195 participants, 139 women were not able to understand and speak the Turkish language well due to their recent immigration. In addition to those, participants who had adolescent pregnancy $(\mathrm{n}=14)$, those who could not adequately complete their questionnaires $(\mathrm{n}=19), 4$ pregnant women with psychiatric disease, and 9 women who were hospitalized due to delivery were excluded. As a result, a total of 1011 participants were included in the statistical analysis.

\section{Sociodemographic characteristics}

Sociodemographic data of the participants are listed in Table 1. The mean age and BMI of the participants were $27.09 \pm 5.55$ years and $27.48 \pm 4.71 \mathrm{~kg} / \mathrm{m}^{2}$ respectively. Mean gestational age (the gestational age when the questionnaire was completed) and parity were $26.20 \pm 9.30$ and $1.47 \pm 1.19$ respectively. $92.7 \%$ of the participants were uneducated, the total household income was low at $73 \%$, middle at $19.88 \%$, and high at

Table 1. Sociodemographic characteristics of the participants $(n=1011)$.

\begin{tabular}{|c|c|c|}
\hline \multicolumn{3}{|c|}{ Demographic data } \\
\hline \multicolumn{2}{|l|}{ Age (years)* } & $27.09 \pm 5.55$ \\
\hline \multicolumn{2}{|l|}{ Pregnancy* } & $2.77 \pm 1.47$ \\
\hline \multicolumn{2}{|l|}{ Parity* } & $1.47 \pm 1.19$ \\
\hline \multicolumn{2}{|l|}{ Abortion* } & $0.41 \pm 0.75$ \\
\hline \multicolumn{2}{|c|}{$\begin{array}{l}\text { Gestational week (mean gestational week } \\
\text { when the questionnaire was completed)* }\end{array}$} & $\begin{array}{c}26.20 \pm 9.30 \\
\text { (range } 13-41 \text { ) }\end{array}$ \\
\hline \multicolumn{2}{|l|}{ BMI $\left(k g / m^{2}\right)^{*}$} & $27.48 \pm 4.71$ \\
\hline \multirow[t]{5}{*}{ Occupation $^{\dagger}$} & Housewife & $58(5.7 \%)$ \\
\hline & Unemployed & $86(8.51 \%)$ \\
\hline & Part-time employee & $217(21.46 \%)$ \\
\hline & Full-time employee & $646(63.9 \%)$ \\
\hline & Other & $4(0.4 \%)$ \\
\hline \multirow[t]{5}{*}{ Education $^{\dagger}$} & None & $938(92.7 \%)$ \\
\hline & Primary and secondary & $30(2.9 \%)$ \\
\hline & High & $15(1.4 \%)$ \\
\hline & University & $4(2.1 \%)$ \\
\hline & Master's degree-Doctorate & $6(0.5 \%)$ \\
\hline \multirow[t]{3}{*}{ Income $^{\dagger}$} & Low (Less than minimum wage) & $738(73.00 \%)$ \\
\hline & Middle (Minimum wage - $4000 \mathrm{TL}$ ) & $201(19.88 \%)$ \\
\hline & High (More than $4000 \mathrm{TL}$ ) & $72(7.12 \%)$ \\
\hline
\end{tabular}

*Values were expressed as mean \pm standard deviation. +Values were calculated as $n$ and $\%$.
$7.12 \%$. While $8.5 \%$ were unemployed, $5.7 \%$ were housewives.

\section{Knowledge of the pregnant women about COVID-19}

The responses of the pregnant women about their knowledge of COVID-19 are shown in Table 2 .

Table 2. Knowledge of pregnant women about COVID-19 ( $n=1011)$.

\begin{tabular}{|c|c|}
\hline & n (\%) \\
\hline \multicolumn{2}{|c|}{ Is it possible that an asymptomatic person is COVID-19 positive? } \\
\hline Yes & $125(12.35 \%)$ \\
\hline No & $170(16.80 \%)$ \\
\hline I don't know & $717(70.85 \%)$ \\
\hline \multicolumn{2}{|c|}{$\begin{array}{l}\text { How many days do pass it to show up the symptoms after being } \\
\text { infected with COVID-19? }\end{array}$} \\
\hline One day & $15(1.48 \%)$ \\
\hline Two days & $32(3.16 \%)$ \\
\hline Three days & $147(14.43 \%)$ \\
\hline Five days & $145(14.23 \%)$ \\
\hline Seven days & $673(66.40 \%)$ \\
\hline \multicolumn{2}{|c|}{ What are the routes of transmission for COVID-19?* } \\
\hline Through close contact & $996(98.51 \%)$ \\
\hline Through blood & $17(1.68 \%)$ \\
\hline I don't know & $101(9.99 \%)$ \\
\hline \multicolumn{2}{|c|}{ What are the routes of transmission for COVID-19?* } \\
\hline High fever & $828(81.89 \%)$ \\
\hline Cough & $229(22.65 \%)$ \\
\hline Loss of smell-taste & $174(17.21 \%)$ \\
\hline Diarrhea & $101(9.99 \%)$ \\
\hline Bleeding & $10(0.98 \%)$ \\
\hline I don't know & $120(11.86 \%)$ \\
\hline \multicolumn{2}{|c|}{$\begin{array}{l}\text { Who are at higher risk of death among those infected with } \\
\text { COVID-19?* }\end{array}$} \\
\hline Those with diabetes & $298(29.47 \%)$ \\
\hline Patients with high blood pressure & $192(18.99 \%)$ \\
\hline Pregnant women & $76(7.51 \%)$ \\
\hline Children & $232(22.94 \%)$ \\
\hline Everyone & $324(32.04 \%)$ \\
\hline I don't know & $220(21.76)$ \\
\hline \multicolumn{2}{|c|}{ What is the minimum duration for proper hand washing? } \\
\hline Less than 5 seconds & $52(5.0 \%)$ \\
\hline Less than 15 seconds & $87(8.5 \%)$ \\
\hline At least 20 seconds & $746(73.7 \%)$ \\
\hline There is no specific time. & $126(12.4 \%)$ \\
\hline \multicolumn{2}{|l|}{ How long can you wear a face mask? } \\
\hline Less than 1 hour & $90(8.7 \%)$ \\
\hline All the time when I am outside & $789(77.7 \%)$ \\
\hline Whole day & $106(10.5 \%)$ \\
\hline I can't stand walking around with a mask & $26(2.6 \%)$ \\
\hline \multicolumn{2}{|l|}{ How do you wear a face mask properly? } \\
\hline Nose and mouth are covered. & $1000(98.9 \%)$ \\
\hline Only mouth is covered. & $11(1.08 \%)$ \\
\hline \multicolumn{2}{|l|}{ Is flu vaccine preventive against COVID-19? } \\
\hline Yes & $192(18.97 \%)$ \\
\hline No & $285(28.06 \%)$ \\
\hline I don't know & $534(52.67 \%)$ \\
\hline
\end{tabular}

*More than one option was chosen. 
According to these results, the question "Is it possible that an asymptomatic person is COVID-19 positive?" was answered as "yes" by $12.3 \%(\mathrm{n}=125)$ of the participants, "no" by $16.8 \%$ (n=170), and "I don't know" by $70.8 \%$ $(\mathrm{n}=717)$. The question "What are the transmission routes of COVID-19?", in which more than one option could be chosen, was answered as "through close contact" by 98.5\% ( $\mathrm{n}=966)$ of the participants, "through blood" by $1.6 \%(\mathrm{n}=17)$, and "I don't know" by $9.9 \%(\mathrm{n}=101)$. While the question "What are the signs to go to the hospital for COVID-19?" was answered as "high fever" by $81.8 \%$ $(n=828)$ of the participants, the question "What is the minimum duration for proper hand-washing?" was answered as "at least 20 seconds" by $73.7 \%(\mathrm{n}=746)$.

\section{Attitudes and risk perceptions of the pregnant women toward COVID-19}

Attitudes and risk perceptions of the pregnant women toward COVID-19 are listed in Table 3. The question "Do you think the authorities take measures for coronavirus pandemic?" was answered as "extremely" by $21.4 \%(n=217)$ of the participants, "highly" by $30 \%$ $(\mathrm{n}=304)$, and "none at all" by $5.7 \%(\mathrm{n}=58)$. The question "How much are you afraid of being infected with COVID-19?" was answered as "extremely" by $43.4 \%$ $(n=440)$ of the participants, the question "Do you think you adequately take measures against COVID-19?" was answered as "highly" by $36.4 \%(\mathrm{n}=369)$, and the question "Do you trust in the healthcare professionals in fighting against COVID-19 pandemic?" was answered as "extremely" by $47.5 \%(\mathrm{n}=481)$. While the question "Have your affection and respect for frontline healthcare professionals increased during COVID-19 pandemic?" was answered as "yes" by $89.1 \%(n=902)$ of the participants, the question "Would you follow the strict requirements if you were asked to be self-quarantined?" was answered as "yes" by $88.5 \%(\mathrm{n}=896)$.

\section{Practices of the pregnant women about COVID-19}

Practices of pregnant women about COVID-19 are listed in Table 4. The question "How often do you wash or disinfect your hands?" was answered as "always" by $45.4 \%(n=459)$. The question "How often do you use a face mask, tissue, or your elbow while sneezing, coughing, or nose flow?" was answered as "always" by $67 \%$ $(n=678)$ of the participants. Of the participants, $42.6 \%$ $(\mathrm{n}=432)$ answered the question "How often do you keep the distance of at least $1-1.5 \mathrm{~m}$ from others?" as "always" and $46.5 \%(n=471)$ answered the question "How often do you follow the news about COVID-19?" as "always".

Table 3. Attitudes and risk perceptions of pregnant women toward COVID-19 ( $n=1011)$.

\begin{tabular}{|c|c|c|c|c|c|c|}
\hline & Extremely & Highly & Moderately & Low & Very Low & None at all \\
\hline $\begin{array}{l}\text { To what extent are the preventive measures } \\
\text { against COVID-19 observed in the society? }\end{array}$ & $155(15.3 \%)$ & $190(8.9 \%)$ & 397 (39.2\%) & $133(13.1 \%)$ & $101(9.9 \%)$ & $42(3.8 \%)$ \\
\hline $\begin{array}{l}\text { Do you think the authorities take measures for } \\
\text { COVID-19 pandemic? }\end{array}$ & $217(21.4 \%)$ & 304 (30\%) & $315(31.1 \%)$ & $90(8.8 \%)$ & $28(2.7 \%)$ & $58(5.7 \%)$ \\
\hline $\begin{array}{l}\text { How much are you afraid of being infected } \\
\text { with COVID-19? }\end{array}$ & $440(43.4 \%)$ & $256(25.3 \%)$ & $218(21.5 \%)$ & $42(4.1 \%)$ & $31(2.9 \%)$ & $24(2.2 \%)$ \\
\hline $\begin{array}{l}\text { Do you think you adequately take measures } \\
\text { against COVID-19? }\end{array}$ & 319 (31.2\%) & 369 (36.4\%) & $256(25.3 \%)$ & $35(3.4 \%)$ & $5(0.4 \%)$ & $27(2.6 \%)$ \\
\hline $\begin{array}{l}\text { Do you think to what extent COVID-19 is a } \\
\text { dangerous and fatal disease? }\end{array}$ & $502(49.6 \%)$ & 320 (31.6\%) & $121(11.9 \%)$ & $21(2.0 \%)$ & $3(0.3 \%)$ & $45(4.4 \%)$ \\
\hline $\begin{array}{l}\text { Do you trust in the healthcare professionals in } \\
\text { fighting against COVID-19 pandemic? }\end{array}$ & $481(47.5 \%)$ & 314 (31.0\%) & $153(15.1 \%)$ & $37(3.6 \%)$ & $3(0.3 \%)$ & $24(2.3 \%)$ \\
\hline & \multicolumn{2}{|c|}{ Yes } & \multicolumn{2}{|l|}{ No } & \multicolumn{2}{|c|}{ I do not know } \\
\hline $\begin{array}{l}\text { Have your affection and respect for frontline } \\
\text { healthcare professionals increased during } \\
\text { COVID-19 pandemic? }\end{array}$ & \multicolumn{2}{|c|}{902 (89.1\%) } & \multicolumn{2}{|l|}{$49(4.8 \%)$} & \multicolumn{2}{|c|}{$61(6.0 \%)$} \\
\hline $\begin{array}{l}\text { Would you follow the strict requirements if you } \\
\text { were asked to be self-quarantined? }\end{array}$ & \multicolumn{2}{|c|}{$896(88.5 \%)$} & \multicolumn{2}{|l|}{$53(5.2 \%)$} & \multicolumn{2}{|c|}{$63(6.2 \%)$} \\
\hline $\begin{array}{l}\text { Did you start any vitamin or nutritional/dietary } \\
\text { supplement due to COVID-19 pandemic? }\end{array}$ & \multicolumn{2}{|c|}{$230(22.75 \%)$} & \multicolumn{2}{|l|}{707 (69.93\%) } & \multicolumn{2}{|c|}{$74(7.32 \%)$} \\
\hline
\end{tabular}


Table 4. Practices of pregnant women about COVID-19 ( $n=1011)$.

\begin{tabular}{|c|c|c|c|c|c|}
\hline & Always & Often & Sometimes & Rarely & Never \\
\hline How often do you wash or disinfect your hands? & $459(45.4 \%)$ & $510(50.1 \%)$ & $33(2.9 \%)$ & $9(0.5 \%)$ & $0(0 \%)$ \\
\hline $\begin{array}{l}\text { How often do you avoid touching your face and } \\
\text { eyes with unwashed hands? }\end{array}$ & $487(48.1 \%)$ & $292(28.8 \%)$ & $129(12.7 \%)$ & $46(4.5 \%)$ & $57(5.6 \%)$ \\
\hline How often do you wear a face mask? & $528(52.2 \%)$ & $308(30.3 \%)$ & $136(13.3 \%)$ & $30(2.8 \%)$ & $9(0.8 \%)$ \\
\hline $\begin{array}{l}\text { How often do you use face mask, tissue or your elbow } \\
\text { while sneezing, coughing or nose flow? }\end{array}$ & $678(67.0 \%)$ & $3(0.3 \%)$ & $217(21.4 \%)$ & $78(7.7 \%)$ & $29(2.8 \%)$ \\
\hline $\begin{array}{l}\text { How often do you regularly disinfect your personal } \\
\text { objects and the surfaces of floor? }\end{array}$ & $471(46.4 \%)$ & $383(37.8 \%)$ & $107(10.4 \%)$ & $28(2.7 \%)$ & $22(2.1 \%)$ \\
\hline How often do you handshake with others? & $23(2.2 \%)$ & $22(2.17 \%)$ & $82(8.10 \%)$ & $210(20.7 \%)$ & $678(67.0 \%)$ \\
\hline How often do you kiss others? & $9(0.8 \%)$ & $3(0.3 \%)$ & $78(7.8 \%)$ & $243(24.0 \%)$ & $678(67.0 \%)$ \\
\hline $\begin{array}{l}\text { How often do you keep the distance of at least } \\
1-1.5 \mathrm{~m} \text { from others? }\end{array}$ & $432(42.6 \%)$ & $263(25.8 \%)$ & $116(11.4 \%)$ & $121(11.8 \%)$ & $79(7.8 \%)$ \\
\hline How often do you follow the news about COVID-19? & $471(46.5 \%)$ & $244(24.1 \%)$ & $213(21.0 \%)$ & $59(5.8 \%)$ & $22(2.1 \%)$ \\
\hline
\end{tabular}

Worries of the pregnant women about COVID-19 pandemic and their knowledge on pregnancy

Worries of the pregnant women about the COVID-19 pandemic and their knowledge on pregnancy are listed in Table 5. While the question "Do you feel yourself more vulnerable/weak as you are pregnant during the pandemic?" was answered as "yes" by $48.3 \%(n=489)$. The question "Do you intend to decrease your antenatal visits during the COVID-19 pandemic?" was answered as "yes" by $50.6 \%(n=512)$ of the participants.

The question "Do you think your baby may be infected after birth?" was answered as "yes" by 39.4\% $(n=401)$ of the participants. The question "Do you think you may be infected just after delivery or during delivery?" was answered as "yes" by $32.5 \%(n=329)$ of the participants and the question "Do you think breastfeeding is safe during COVID-19 pandemic?" was answered as "yes" by 70.4\% (n=715). The question "Do you think of changing your delivery method (cesarean or vaginal delivery) due to COVID-19?" was answered as "no" by $56.6 \%(\mathrm{n}=572)$, and the question "Do you think COVID-19 will cause disability in your child?" was answered as "I don't know" by $71.8 \%$ (n=727). In addition, the question "Do you think COVID-19 will cause preterm delivery?" was answered as "I don't know" by $70.5 \%(\mathrm{n}=714)$ of the participants.

\section{Discussion}

This study aimed to assess the pregnant women's level of awareness, knowledge, behavior, and attitude toward COVID-19 disease. The following conclusions were made as a result of the study: (1) Affection and respect of the pregnant women for healthcare profes-

Table 5. Worries of pregnant women about COVID-19 and their knowledge on pregnancy $(n=1011)$.

\begin{tabular}{|c|c|c|c|}
\hline & Yes & No & I do not know \\
\hline Do you feel yourself more vulnerable/weak as you are pregnant during the pandemic? & $489(48.3 \%)$ & $389(38.4 \%)$ & $134(13.2 \%)$ \\
\hline Do you intend decreasing your antenatal visits during COVID-19 pandemic? & $512(50.6 \%)$ & $273(27 \%)$ & $226(22.3 \%)$ \\
\hline Do you continuously think you are infected with COVID-19? & $764(75.4 \%)$ & $121(11.9 \%)$ & $126(12.3 \%)$ \\
\hline Do you think your baby may be infected after birth? & $401(39.4 \%)$ & $303(29.7 \%)$ & $308(30.2 \%)$ \\
\hline Do you think you may be infected just after delivery or during delivery? & $329(32.5 \%)$ & $312(30.7 \%)$ & $370(36.4 \%)$ \\
\hline Do you think breastfeeding is safe during COVID-19 pandemic? & $715(70.4 \%)$ & $80(7.9 \%)$ & $214(21.0 \%)$ \\
\hline Do you think of changing your delivery method (cesarean or vaginal delivery) due to COVID-19? & $124(12.2 \%)$ & $572(56.6 \%)$ & $313(31.0 \%)$ \\
\hline Do you think COVID-19 will cause disability in your child? & $33(3.2 \%)$ & $252(24.9 \%)$ & $727(71.8 \%)$ \\
\hline Do you think COVID-19 will cause preterm delivery? & $147(14.4 \%)$ & $150(14.7 \%)$ & $714(70.5 \%)$ \\
\hline
\end{tabular}


sionals increased and they had a positive attitude during the COVID-19 pandemic, (2) Their worries and anxiety about the COVID-19 pandemic were high, and (3) Most of them had lack of knowledge on how their pregnancy processes would be affected and how their baby would be affected by COVID-19 after birth. Moreover, it was concluded that about half of the participants followed the requirements of quarantine, and mask, distance, and hygiene rules.

The clinical course of COVID-19 in pregnant women has not yet been fully understood; however, according to the recommendations of WAPM-World Association of Perinatal Medicine, including both highincome and low-to middle-income countries, and it seems that maternal mortality rates have not increased much in COVID-19 so far unlike in previous H1N1 and SARS pandemics; however, we recommend to be cautious in calculating estimates of attributable risk with pregnancy. ${ }^{[10,11]}$ In the INTERCOVID Multinational Cohort Study, which was conducted with the participation of 18 countries, it was reported that COVID-19 was associated with consistent and substantial increases in severe maternal morbidity and mortality and neonatal complications during pregnancy. ${ }^{[12]}$ Understanding the knowledge of a specific population such as pregnant women about COVID-19 can be an important tool in developing and applying training strategies and interventions about COVID-19 in the future. The results of this study represent the general knowledge of a group of pregnant women in Turkey about the COVID-19 pandemic and the effects of this pandemic on pregnancy.

It was reported in a study in Turkey that pregnant women trusted the authorities (65\%) and healthcare professionals $(92.4 \%)$ in fighting against the pandemic and that their respect for these people increased $(82.5 \%)$ during the pandemic. ${ }^{[13]}$ Similarly, while the trust in healthcare professionals was found "very high/extreme" by $47.5 \%$ and "high" by $31 \%$, the affection and respect for healthcare professionals increased in $89.1 \%$ of the participants in our study. Recent violence tendency toward healthcare professionals is a critical world problem and this condition causes loss of performance and motivation in healthcare professionals. Observing that emotional bonds between patients and healthcare professionals are strengthening in such a period with high anxiety and tension level like pandemic is a very important and pleasing result. Similarly, about $61.4 \%$ (21.4\% extremely and $30 \%$ highly) of the participants stated that authorities took adequate measures against COVID-19 and $88.5 \%$ stated that they would be in cooperation with the authorities by self-quarantining when necessary.

In a recent cohort study in China, an increase in the prevalence of perinatal depression due to the pandemic has been reported, ${ }^{[14]}$ and according to the study, pregnant women are more sensitive to panic conditions regarding the general population and masses. Although our study is not the one determining the anxiety levels, almost half $(48.3 \%)$ of the participants stated that they felt more vulnerable and weaker as they were pregnant during the pandemic. This is consistent with the increasing anxiety levels and sensitivity to panic conditions in pregnant women. In a study on the H1N1 pandemic in 2013, the group who was the most afraid of being infected included pregnant women and parents with a little child. ${ }^{[15]}$

In a survey study assessing knowledge and attitudes of pregnant women about COVID-19 in Iran, although most of the participants were moderately worried about being infected with COVID-19, about half of them stated that they were mostly worried that their babies would be infected with COVID-19 after birth and two-third of the participants stated that they were worried that their babies would die due to COVID-19. ${ }^{[16]}$ It was reported in another study in Turkey that less than half of the pregnant participants had this concern. ${ }^{[13]}$ In our study, although $39.4 \%$ of the participants were worried that their baby would be infected after birth, 30.2\% had no idea about that issue. Although $24.9 \%$ of the participants thought COVID19 would not cause disability in their babies $71.8 \%$ had no idea about this issue. These high anxiety levels of the pregnant women about their babies may be because of the limited data about the effects of COVID-19 on newborns. It was reported in the study in Iran that most of the pregnant women decreased or ended their routine antenatal follow-ups due to these concerns. ${ }^{[16]}$ Similarly, it was reported in a study in Shanghai that pregnant women were willing to decrease their antenatal visits, especially in the second trimester. ${ }^{[17]}$ However, it has been reported that a decrease in antenatal follow-ups due to the concern of COVID-19 may increase negative pregnancy outcomes and it has been emphasized that healthcare professionals must be careful about this issue. ${ }^{[18]}$ It has also been reported that there may be delays in early detections of the fetus with anomaly and therefore, the healthcare professionals 
must be careful that the legal period of abortions may expire in that case. ${ }^{[16]}$ Similarly, $50.6 \%$ of the pregnant women intended to decrease their antenatal visits due to COVID-19 in our study.

As a result of this study, general knowledge and awareness of COVID-19 were found to be at considerably high rates. It has been found in questionnaires assessing knowledge, attitude, and behaviors toward COVID-19 in different countries such as Nigeria, China, the United States of America and Bangladesh that pregnant women have reasonable knowledge of COVID-19. ${ }^{[19-21]}$ This may be because all the world is on alert against the pandemic, governments are in cooperation with their citizens, showing maximum effort to prevent the pandemic, and social media tools inform and train masses with various methods. However, we cannot generalize this consciousness level because contrary views have also been reported in the literature; and in a study in Thailand, $74.1 \%$ of the women had a lack of knowledge on COVID-19. ${ }^{[2]}$

Although the rate of correct answers to the transmission routes of COVID-19 in questionnaires in the literature was $80 \%$ in a study in $\operatorname{Iran}^{[16]}$ and $82.3 \%$ in Bangladeshi women, ${ }^{[20]}$ it was $98.51 \%$ in our study, which is consistent with the findings in the literature. In the same study in Iran, the rate of knowledge on the symptoms of COVID-19 was reasonably high. ${ }^{[16]}$ This level of knowledge was also reasonably high in our study $(81.89 \%, 22.65 \%$, and $17.21 \%$ for high fever, cough, and loss of smell-taste, respectively). In some studies, high levels of knowledge and awareness on COVID-19 were associated with living in urban regions, receiving higher education, and having an occupation. ${ }^{[21]}$ Although $92.7 \%$ of the participants in our study were uneducated and $73 \%$ had low incomes, the level of knowledge and awareness was high. These differences among studies may be due to the policies of countries to prevent COVID-19.

The main limitations of this study were that it was a cross-sectional study and that it was performed in a secondary care hospital. In addition, it was performed in a single city in Turkey, and therefore, it cannot be generalized for the whole country. The pregnant women who were in their first 12 weeks and who did not have the adequate mental maturity to answer the questions about birth such as preterm delivery or breastfeeding according to us were not included in the study. However, we believe this study that was per- formed with a large number of participants will help pregnant women to realize that they need good counseling to mentally have a more comfortable pregnancy during the pandemic and to anticipate their needs in this regard.

\section{Conclusion}

In conclusion, pregnant women's level of knowledge, attitude, and awareness of COVID-19 were high in this study. They also had anxiety and worries about their babies. Moreover, affection, respect, and positive attitudes of pregnant women toward healthcare professionals and authorities increased. The cooperation of administrators, healthcare professionals, and patients is quite important in fighting against the pandemic. The measures taken can be applied with high awareness of COVID-19. Sufficient training, in that case, can be done through communication routes such as information and public service announcements.

Funding: This work did not receive any specific grant from funding agencies in the public, commercial, or not-for-profit sectors.

Compliance with Ethical Standards: The authors stated that the standards regarding research and publication ethics, the Personal Data Protection Law and the copyright regulations applicable to intellectual and artistic works are complied with and there is no conflict of interest.

\section{References}

1. Sahu KK, Mishra AK, Lal A. Comprehensive update on current outbreak of novel coronavirus infection (2019-nCoV). Ann Transl Med 2020;8:393. [PubMed] [CrossRef]

2. Di Mascio D, Khalil A, Saccone G, Rizzo G, Buca D, Liberati $\mathrm{M}$, et al. Outcome of coronavirus spectrum infections (SARS, MERS, COVID-19) during pregnancy: a systematic review and meta-analysis. Am J Obstet Gynecol MFM 2020;2:100107. [PubMed] [CrossRef]

3. Schwartz DA, Graham AL. Potential maternal and infant outcomes from coronavirus 2019-NCOV (SARS-CoV-2) infecting pregnant women: lessons from SARS, MERS, and other human coronavirus infections. Viruses 2020;12:194. [PubMed] [CrossRef]

4. Yang H, Sun G, Tang F, Peng M, Gao Y, Peng J, et al. Clinical features and outcomes of pregnant women suspected of coronavirus disease 2019. J Infect 2020;81:e40-4. [PubMed] [CrossRef]

5. Shilpa K, Praveen Kumar B, Kumar SY, Ugargol A, Naik V, Mallapur M, et al. A study on awareness regarding swine flu (influenza A H1N1) pandemic in an urban community of Karnataka. Medical Journal of Dr. D. Y. Patil University 2014; 7:732-7. [CrossRef] 
6. Al-Johani MM, Al-Qahtani AM. Prevalence and risk factors of anxiety among Saudi male secondary schools' students in Madinah, Saudi Arabia. International Journal of Medical Science and Public Health 2016;5:994-9. [CrossRef]

7. Nalongsack S, Yoshida Y, Morita S, Sosouphanh K, Sakamoto J. Knowledge, attitude and practice regarding dengue among people in Pakse, Laos. Nagoya J Med Sci 2009; 71:29-37. [PubMed]

8. Cheng $\mathrm{C}, \mathrm{Ng} \mathrm{AK}$. Psychosocial factors predicting SARS-preventive behaviors in four major SARS-affected regions. J Appl Soc Psychol 2006;36:222-47. [CrossRef]

9. Gynaecologists RCoOa. Coronavirus (COVID-19) infection in pregnancy: information for healthcare professionals (version 6). [Internet]. [cited 3 April 2020]. Available from: https://www.rcog.org.uk/globalassets/documents/guidelines/2020-04-03-coronavirus-covid-19-infection-in-pregnancy.pdf

10. Di Mascio D, Sen C, Saccone G, Galindo A, Grünebaum A, Yoshimatsu J, et al. Risk factors associated with adverse fetal outcomes in pregnancies affected by Coronavirus disease 2019 (COVID-19): a secondary analysis of the WAPM study on COVID-19. J Perinat Med 2020;48:950-8. [PubMed] [CrossRef]

11. Api O, Sen C, Debska M, Saccone G, D’Antonio F, Volpe N, et al. Clinical management of coronavirus disease 2019 (COVID-19) in pregnancy: Recommendations of WAPMWorld Association of Perinatal Medicine. J Perinat Med 2020;48:857-66. [PubMed] [CrossRef]

12. Villar J, Ariff S, Gunier RB, Thiruvengadam R, Rauch S, Kholin A, et al. Maternal and neonatal morbidity and mortality among pregnant women with and without COVID-19 infection: the INTERCOVID Multinational Cohort Study. JAMA Pediatr 2021;175:817-26. [PubMed] [CrossRef]

13. Yassa M, Birol P, Yirmibes C, Usta C, Haydar A, Yassa A, et al. Near-term pregnant women's attitude toward, concern about and knowledge of the COVID-19 pandemic. J Matern Fetal Neonatal Med 2020;33:3827-34. [PubMed] [CrossRef]

14. Wu Y, Zhang C, Liu H, Duan C, Li C, Fan J-X, et al. Perinatal depressive and anxiety symptoms of women during the Coronavirus disease 2019 outbreak in China. Am J Obstet Gynecol 2020;232:240.e.1-9. [PubMed] [CrossRef]

15. Braunack-Mayer A, Tooher R, Collins JE, Street JM, Marshall $\mathrm{H}$. Understanding the school community's response to school closures during the H1N1 2009 influenza pandemic. BMC Public Health 2013;13:344. [PubMed] [CrossRef]

16. Maharlouei N, Asadi N, Bazrafshan K, Roozmeh S, Rezaianzadeh A, Zahed-Roozegar M-H, et al. Knowledge and attitude regarding COVID-19 among pregnant women in Southwestern Iran in the early period of its outbreak: a cross-sectional study. Am J Trop Med Hyg 2020;103:236875. [PubMed] [CrossRef]

17. Du L, Gu YB, Cui MQ, Li WX, Wang J, Zhu LP, et al. Investigation on demands for antenatal care services among 2 002 pregnant women during the epidemic of COVID-19 in Shanghai. [Article in Chinese] Zhonghua Fu Chan Ke Za Zhi 2020;5 5:160-5. [PubMed] [CrossRef]

18. Coxon K, Turienzo CF, Kweekel L, Goodarzi B, Brigante L, Simon A, et al. The impact of the coronavirus (COVID-19) pandemic on maternity care in Europe. Midwifery 2020;88: 102779. [PubMed] [CrossRef]

19. Clements JM. Knowledge and behaviors toward COVID-19 among us residents during the early days of the pandemic: cross-sectional online questionnaire. JMIR Public Health Surveill 2020;22:e19161. [PubMed] [CrossRef]

20. Mannan KA, Farhana KM. Knowledge and perception towards Novel Coronavirus (COVID-19) in Bangladesh. International Research Journal of Business and Social Science 2020;6:76-87.

21. Nwafor JI, Aniukwu JK, Anozie BO, Ikeotuonye AC, OkedoAlex IN. Pregnant women's knowledge and practice of preventive measures against COVID-19 in a low-resource African setting. Int J Gynecol Obstet 2020;150:121-3. [PubMed] [CrossRef]

22. Srichan P, Apidechkul T, Tamornpark R, Yeemard F, Khunthason S, Kitchanapaiboon S, et al. Knowledge, attitudes and preparedness to respond to COVID-19 among the border population of northern Thailand in the early period of the pandemic: a cross-sectional study. WHO South-East Asia J public Heal 2020;9:118-25. [PubMed] [CrossRef]

This work is licensed under the Creative Commons Attribution-NonCommercial-NoDerivs 4.0 Unported (CC BY-NC-ND4.0) License. To view a copy of this license, visit http://creativecommons.org/licenses/by-nc-nd/4.0/ or send a letter to Creative Commons, PO Box 1866, Mountain View, CA 94042 , USA.

Publisher's Note: The content of this publication does not necessarily reflect the views or policies of the publisher, nor does any mention of trade names, commercial products, or organizations imply endorsement by the publisher. Scientific and legal responsibilities of published manuscript belong to their author(s). The publisher remains neutral with regard to jurisdictional claims in published maps and institutional affiliations. 